\title{
Gradient Modification of Fingerprint Images using Fingerpint Area and Contour
}

\author{
Hideyo Takeuchi Member (Chuo Spring Co.Ltd, DDS Incorporated) \\ Masahiro Hoguro Non-member (Nagoya Institute of Technology) \\ Noriyuki Matsumoto Non-member (Chuo Sp ring Co.Ltd) \\ Taizo Umezaki Member (Nagoya Institute of Technology)
}

Keywords : fingerprint verification, fingerprint identification, tilted fingerprint, gradient modification

In this paper, we describe the way to improve the usability of fingerprint verification devices, especially for users who don't get used to the devices. Beginning users of fingerprint verification devices tend to input his finger tilted on scanner. So, in some cases, he has difficulty for identifying himself by using his finger and fingerprint verification devices. So the function for modifying fingerprint gradient carry great weight for fingerprint verification devices.

Fig 1 shows the fingerprint area and contour extracted by our algorithm, which is utilized for gradient modification of fingerprint images. Our algorithm does not need to extract end points or bifurcation points called minutia from fingerprint images. It takes $3.2[\mathrm{~ms}]$ to modify the gradient by personal computer which operates at $1000[\mathrm{MHz}]$ clock frequency. Thus, our algorithm is fast enough to be embedded in fingerprint verification devices that operate at lower speeds.

We evaluate our algorithm by using fingerprint images tilted 0 [degree], 5[degree], 10[degree] and 15[degree]. Fig 2 shows recognition rate with respect to each rotation angle, while type II error is fixed at $0.01[\%]$.

Without gradient modification, recognition rate calclated from non tilted images is $98.4[\%]$. Recognition rate calclated from 5[degree], 10[degree] and 15[degree] tilted images are respectively $84.7[\%], 26.3[\%]$ and $8.2[\%]$. As tilted angle is larger, recognition rate becomes lower. Especially, recognition rate is $8.2[\%]$ when input images are tilted 15 [degree].

By modifying gradient using fingerprint area, recognition rate at 15[degree] tilted images is improved from 8.2[\%] to $65.5[\%]$ ]. Additionary, by modifying gradient using fingerprint area and

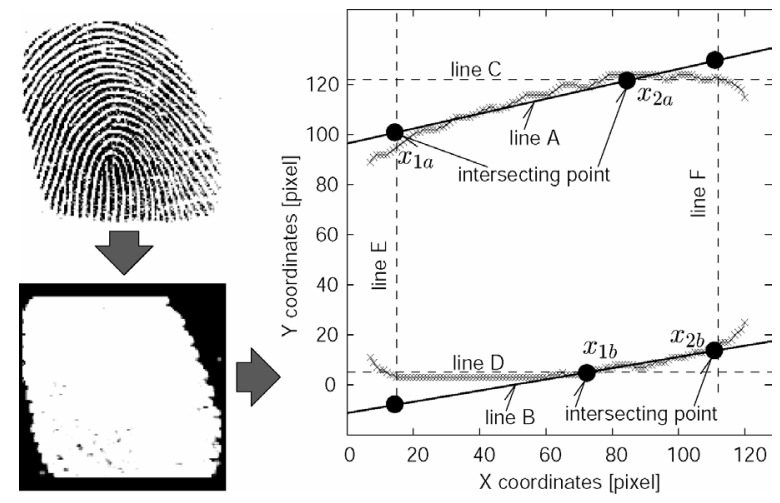

Fig. 1. Extraction of fingerprint area and contour for calculating rotation angle contour, recognition rate is improved to $81.6[\%]$.

It is exceptional that input image is tilted at 15 [degree] in a real world, when a user identify himself by using the device which has finger guide. But, by adopting this algorithm, usability of fingerprint verification devices will be advanced in a great deal and become more friendry to beginning users.

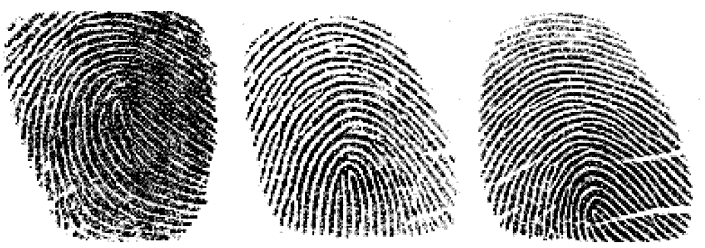

(a) Fingerprint images before gradient modification
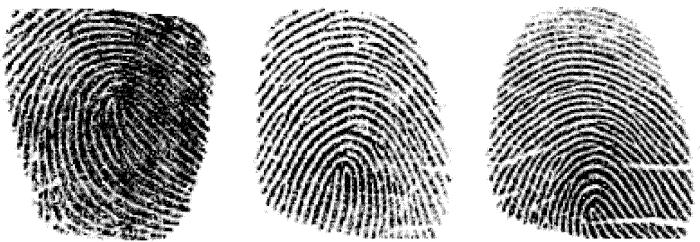

(b) Fingerprint images after gradient modification

Fig. 2. Tilted fingerprint images

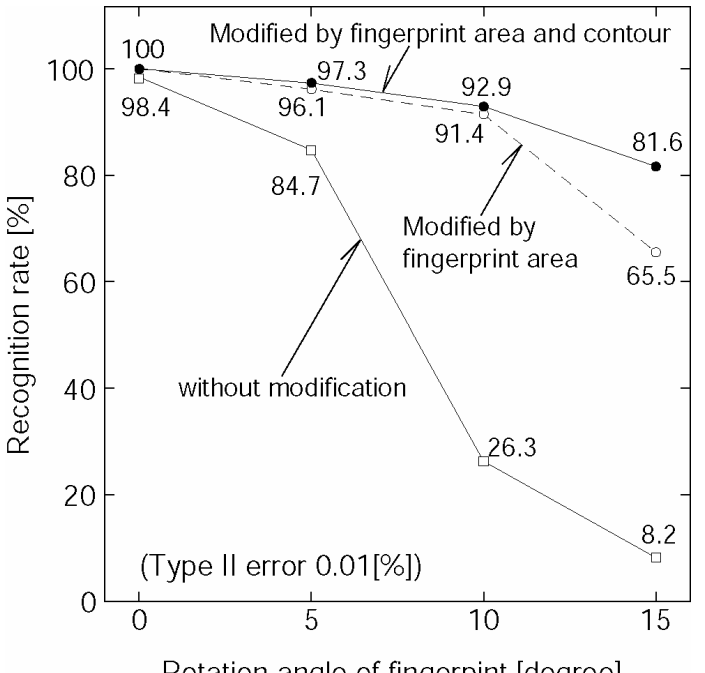

Fig. 3. Recognition rate with respect to each rotation angle 


\title{
指紋領域・輪郭情報を用いた指紋画像の回転補正法
}

\author{
正 員 竹内 英世*,** 非会員 保黒 政大*** \\ 非会員 松本 憲幸* 正 員 梅崎 太造***
}

\section{Gradient Modification of Fingerprint Images using Fingerpint Area and Contour}

Hideyo Takeuchi ${ }^{* * *}$, Member, Masahiro Hoguro ${ }^{* * *}$, Non-member, Noriyuki Matsumoto*, Non-member, Taizo Umezaki***, Member

In this paper, we propose the way to modify gradient of fingerprint images. We modify the gradient using fingerprint area and contour, without extracting end points or bifurcation points called "minutia" from fingerprint images. It takes $3.2[\mathrm{~ms}]$ to modify fingerprint gradient by using a personal computer which operates at $1000[\mathrm{MHz}]$ clock frequency. Our program code is so light weight that it is able to be embedded in fingerprint verification devices which operate at lower speeds. We evaluated our algorithm by using fingerprint images tilted respectively $0^{\circ}, 5^{\circ}, 10^{\circ}$ and $15^{\circ}$. Without modifying gradient, we achieved 90.8[\%] recognition rate by images tilted from $0^{\circ}$ to $5^{\circ}$, while false acceptance rate is $0.01[\%]$. By using our gradient modification algorithm, recognition rate raised from 90.8[\%] to 98.2[\%]. On the other hand, 19.4[\%] recognition rate was achieved by images tilted from $10^{\circ}$ to $15^{\circ}$ without gradient modification, and the rate raised to 89.2[\%] with gradient modification. The users who don’t get used to fingerprint devices tend to input his finger tilted on scanner. Thus, it is expected that the fingerprint verirification device will be improved to be more friendly for all peoples, by using our gradient modification algorithm.

キーワード：指紋照合，指紋認証，傾き入力，回転補正

Keywords: fingerprint verification, fingerprint identification, tilted fingerprint, gradient modification

\section{1. まえがき}

2005 年 4 月より施行された個人情報保護法, 近い将来施 行される日本版 SOX 法などの新時代の法律は, 我々を取り 巻く社会環境に急激な変化を与えようとしている。企業に おいては，必要な情報を安全に活用するための情報セキュ リテイ対策やリスク管理が必須の課題となりつつある。重 要エリアへの入退出管理は勿論のこと, 個人情報や機密情

\footnotetext{
*中央発條（株）キャブレックス部

干 470-0225 愛知県西加茂郡三好町大字福田字宮下 43 番地の 1 Cablex Division, Chuo Spring Co.Ltd

Technical Center, 43-1 Miyashita Fukuta, Miyoshi-cho Nishikamo-gun, Aichi-ken, 470-0225 Japan

** (株) ディー・ディー・エス

₹ 450-0003 名古屋市中村区名駅南一丁目 27 番 2 号 日本生命笹島ビル $16 \mathrm{~F}$

DDS Inc, Nihon Seimei Sasashima Bldg 16F, 1-27-2 Meiekiminami, Nakamura-ku, Nagoya, 450-0003 Japan

*** 名古屋工業大学大学院工学研究科

干 466-8555 愛知県名古屋市昭和区御器所町

Graduate School of Engineering, Nagoya Institute of Technology, Gokiso-cho, Showa-ku, Nagoya-shi, Aichi, 466-8555 Japan
}

報に“誰が何時アクセスをしたのか？”“誰がアクセス権を 持つか?”を管理できる体制の整備が急務となっている。

このような状況下で, 指紋, 顔, 虹彩, 掌紋など, 人間 の身体的特徴を用いて個人を特定できるバイオメトリック (生体認証) 技術の必要性はますます高まっている。生体 認証技術の中でも，指紋認証は，万人不同・終生不变とい う 2 大特性を持ち，比較的低コストで装置化が実現する。 そのため, 指紋による個人識別の研究は盛んに行われてき た (1) (21)。近年では，指紋照合技術は空港や国境における 入国管理，企業に扔けるコンピュータのネットワークセキュ リティを強化する技術として採用されている。また，我々 の身近なところでは携带電話の個人認証用途や, 住宅に設 置される鍵の代わりとして使用されている。

しかし，これらの指紋照合装置を万人が利用できるょう になるためには，いまだ以下 (1)，(2)の課題が残ることが 指摘されている(1)(4)(6)。

（1）乾燥指・かすれ等の低品質な指紋画像への対処 老人や水仕事を頻繁に行う主婦からは明瞭な指紋画 像が採取されず，照合困難となる問題がある。

（2）斜め入力・位置ずれやひずみへの耐性強化 
例えば，指紋照合装置に慣れていない初心者は，指 を斜めに置くことがあるため，誤認証を起こす確率 が高くなる。

我々は，これまで特に (1) の問題に強い指紋照合方式と して群遅延スペクトルによる方法を提案してきた (10)(11)。 また，(1) の問題については実環境で動作する指紋照合装 置に即組み込み可能な改善手法を提案してきた ${ }^{(12)(13)}$ 。

個人住宅や企業の重要エリアに設置される指紋照合装置 は，部屋に入ろうとする人を迅速・確実に認証する必要が ある。携帯電話などに搭載される指紋認証機能に比べ, 数 段高い個人認証性能と装置の完成度が要求される。誰にで も使い易い指紋照合装置を造るためには，さらに(2)の斜 め入力・位置ずれやひずみへの耐性強化について検討が必 要である。

本論文では，実環境で動作する指紋照合装置への搭載に 適した，指紋の斜め入力対策法について述べる。処理が軽 いため，ハードウェア資源の限られた組み込み機器の $\mathrm{CPU}$ に負担をかけずに対策できる利点がある。

\section{2. 実環境における指紋の傾き入力対策}

各社から製品化されている入退出管理用途の指紋照合装 置の多くは，ハードウェア・ソフトウェアの両面から指紋 の傾き入力対策を施している。ハードウェア的な指紋の傾 き入力対策としては，指紋入力部に指ガイドを設けるのが 一般的である ${ }^{(16) \sim(20)}$ 。また，指紋センサに静電気対策の指 ガイド付きのシャッターを設けた指紋照合装置もある ${ }^{(21)}$ 。 ガイドに指を当ててシャッターを開ける動作により，指は 真っ直ぐに置かれるため, これも傾き入力対策として効果 がある。

実環境で動作する指紋照合装置では，ハードウェアによ る傾き入力対策を行ったうえで，さらに画像処理技術を用 いたソフトウェアによる対策を施しているものが多い。以 下，市販の指紋照合装置に採用されているソフトウェアに よる傾き入力対策法について説明する。指紋照合技術は，指 紋画像から指紋のマニューシャ（端点・分岐点）などの局 所的情報を抽出して照合を行うマニューシャマッチング方 式と, 指紋原画像や周波数特徵量などの大局的情報を抽出 して照合を行う方式に大別される。指紋の回転補正法もそ れぞれの特徵抽出法に適した方式が提案されている。

マニューシャ特徵量を利用した回転指紋画像への対処法 は, 多くの研究者により提案され, 犯罪捜査用途をはじめ とした指紋照合装置に採用されている(3)(9)(14)。これらの 方法では，明瞭な指紋画像が採取されれば高い回転角度検 出能力, 個人認証精度を発揮する。しかし, マニューシャ 抽出は処理が複雑で, 装置化には高速な CPU や専用 LSI が必要なため, 装置のコストアップにつながる。また, 老 人や水仕事を頻繁に行う主婦など “乾燥指”を持つユーザ の指からは特徵点や指紋隆線方向の抽出が困難となり, 回 転補正や個人認証ができない問題がある。

一方，指紋画像の大局的な情報を用いた回転補正方法と

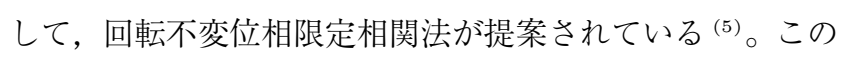
方法では，指紋画像を極座標变換して周波数分析を行い，周 波数空間上での位相相関を評価することにより回転補正を 行う。位相限定相関分析の専用 LSI を組み込んた指紋照合 装置の構成にはこの方式は適している ${ }^{(5)}$ 。また, 乾燥指・ かすれ指紋画像に対しても回転補正できる利点がある。し かし, 指紋画像の回転補正のために二次元 FFT 演算が必 要となり, 計算量が増大するため, 汎用の指紋照合装置へ の組み込み用途には適さない。

また，入力画像または登録画像を回転させた回転指紋画 像を生成し, 回転補正用の特徵を抽出することで斜め入力 に対処する方法もある(4)(7)。これは既存の指紋照合装置に も比較的簡単に応用できる方法ではあるが, 複数枚の指紋 画像から特徴抽出を行う必要があるため, 装置のハードウェ ア構成によっては，照合速度の面で不利になる場合がある。

本論文では，低速な CPUを搭載した組み込み型の指紋 照合装置にも採用できる指紋の傾き入力対策法について検 討する。指紋の領域情報・輪郭情報のみを用いて傾きを補 正するため, マニューシャ特徵点を抽出できないかすれ気 味の指紋画像に対応できる利点もある。

\section{3. 評価用指紋画像データベース}

指紋採取は，Authentec 社製 AF-S2 半導体センサが搭 載された中央発條（株）製 指紋照合装置の指紋読み取り部 を使って採取する（図 1 参照）。指紋照合装置が利用され る実環境に最も近い状態を再現し，指紋画像採取を行う。3 月の初春に採取した 51 人分，一人につき 25 枚の指紋デー 夕を照合実験に用いる。128×128[pixel], 白黒 256 階調 のデータである。

一人につき 25 個の指紋画像のうち，10 枚は指を指紋セ ンサ上にまっすぐ置いたもの，5枚は 5 ○の傾きをつけて置 いたもの，5枚は $10^{\circ}$ の傾きをつけて置いたもの，残りの 5 枚は $15 \circ$ の傾きをつけて置いたものである。図 1 の右図 に示すように, 指紋照合装置の指紋読み取り部に $0^{\circ}, 5^{\circ}$, $10^{\circ}, 15^{\circ}$ の目盛りをつけ, 被験者にはその目盛りにあわ せて指を置いて頂き指紋採取を行った。ただし, 被験者全

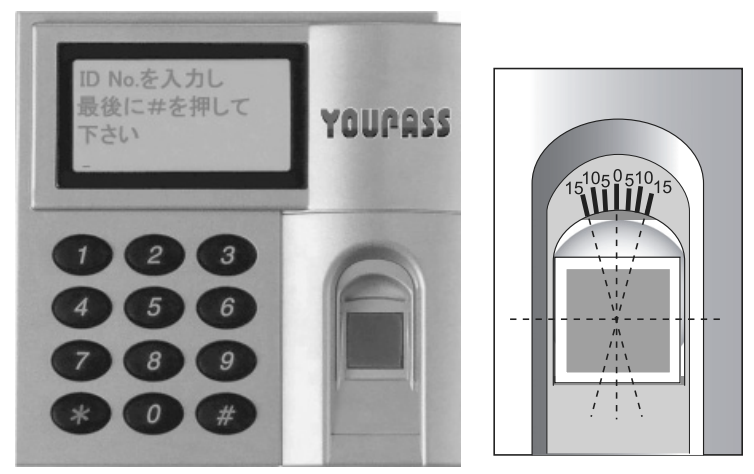

図 1 指紋照合装置と回転指紋採取方法

Fig. 1. Fingerprint identification device and capturing rotated fingerprint images 


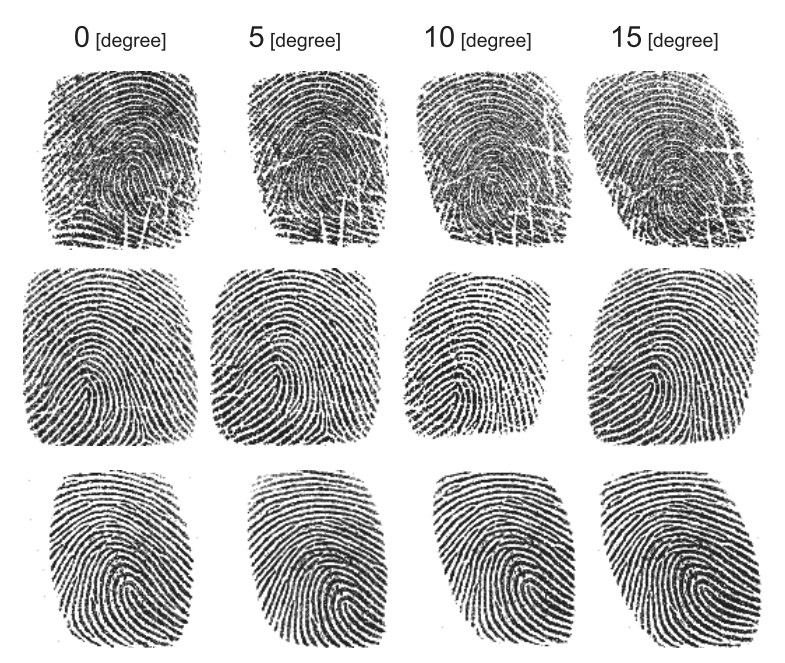

図 2 回転して押捺された指紋画像の例

Fig. 2. Tilted fingerprint images

員が指の傾きと目盛りの傾きを完全に一致させるのは難し い。採取された指紋画像は, 目盛りの角度より傾きが小さ めのものもあれば，大きめのものもある。図 2 に採取指紋 画像の例を示す。

\section{4. スペクトルを用いた指紋照合法}

図 3 に指紋画像からの特徴抽出例を示す。指紋画像（図 3(a)）に平滑化フィルタ（図 3(b)）をかけた後, 群遅延スペ クトル (Group Delay Spectrum:GDS) を算出する。GDS の先鋭化を抑制する平滑化係数は 0.92 , 線形予測次数は 10 次，チャネル数は 16 とする。GDS は指紋隆線の幅等にみ られる指紋らしさの情報を削減し, 個人性情報を強める働 きがある(11)。

登録指紋から抽出した GDS と入力指紋から抽出した GDS に対し，移動照合を行ったときの最小距離を 2 つの指 紋データの距離（非類似度）とする。図 4 は, 同一指から 抽出した 2 つの GDS パターンについて照合を行ったとき の距離特性である。通常はずらし幅 $w d$ を [-40:40] の範 用で増分 1 でずらして最小距離 $\operatorname{dist}\left(w d_{\text {min }}\right)$ を探索する。

$x$ 方向 GDS から算出した距離 $d^{2} s t_{x}$ と, $y$ 方向 GDS か ら算出した距離 $d i s t_{y}$ を式 (1)により合成し, 距離尺度 $D$ を求める。重み係数 $w$ は 0.7 を用いる。

$$
D=w \times d i s t_{x}+(1-w) \times d i s t_{y}
$$

\section{5. 指紋領域・輪郭情報を用いた回転補正法}

〈5・1〉 領域情報による重心と傾き角の算出 指紋画 像 $F_{i, j}(i, j=0,1, \cdots, 127)$ に(2) 式・(3) 式で示される差 分フィルタをかけ指紋隆線と谷線を塗りつぶした指紋領域 画像 $M_{i, j}$ を作成する。なお，指紋領域 $M_{i, j}$ には 2 值化を 行わないため, $M_{i, j}$ は $0 \sim 255$ の階調值を持っている。図 5 (a) に指紋原画像 $F_{i, j}$, 図 5(b) に指紋領域画像 $M_{i, j}$ の例 を示す。

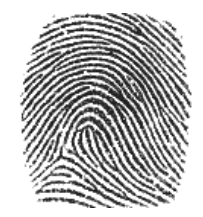
image (a) Fingerprint

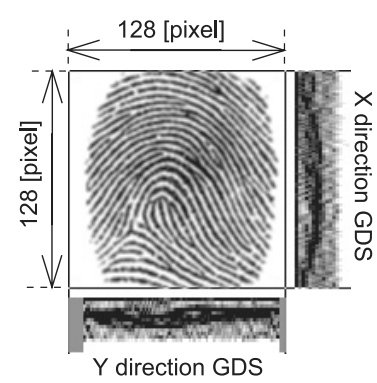

(c) GDS patterns
図 3 特徵抽出法

Fig. 3. Feature extraction from fingerprint image

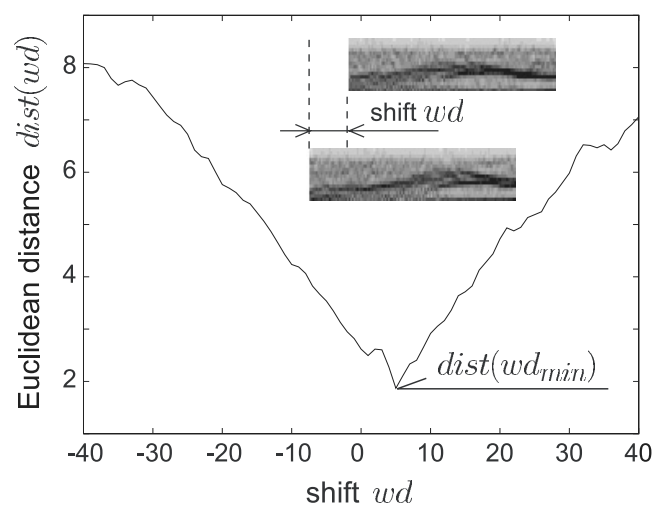

図 4 GDS による距離計算法

Fig. 4. GDS pattern matching and distance

$$
\begin{aligned}
& G_{i, j}=\sum_{l=j}^{j+3} \sum_{k=i}^{i+2}\left|F_{k, l}-F_{k+1, l}\right| \cdots \ldots \ldots \ldots \ldots \\
& M_{i, j}=\left\{\begin{array}{ll}
255 & \left(G_{i, j}>255\right) \\
G_{i, j} & \left(0 \leq G_{i, j} \leq 255\right)
\end{array} \quad \cdots \ldots \ldots .\right.
\end{aligned}
$$

次に，(4) 式〜 (8) 式を用いて指紋領域画像の重心 $\left(\mu_{i}, \mu_{j}\right)$ と傾き角度 $\theta_{m}$ を算出する。

$$
\begin{aligned}
\mu_{i} & =\frac{1}{128 \times 128} \sum_{j=0}^{127} \sum_{i=0}^{127} i M_{i, j} \ldots \ldots \ldots \\
\mu_{j} & =\frac{1}{128 \times 128} \sum_{j=0}^{127} \sum_{i=0}^{127} j M_{i, j} \ldots \ldots \ldots \\
\sigma_{j}^{2} & =\frac{1}{128 \times 128} \sum_{j=0}^{127} \sum_{i=0}^{127} j^{2} M_{i, j}-\mu_{j}^{2} \ldots \\
\sigma_{i j}^{2} & =\frac{1}{128 \times 128} \sum_{j=0}^{127} \sum_{i=0}^{127} i j M_{i, j}-\mu_{i} \mu_{j} \\
\theta_{m} & =\tan ^{-1}\left(\frac{\sigma_{i j}^{2}}{\sigma_{j}^{2}}\right) \ldots \ldots . \cdots
\end{aligned}
$$

これらの式は $M_{i, j}$ の濃淡を考慮した最小二乗法による 直線近似の式である。(4) 式〜 (8) 式に $M_{i, j}$ の濃淡情報が 反映されることで指紋領域が曖昧なかすれ指紋画像からも 重心と傾き角度を算出することができる。処理が軽いため, 
ハードウェア資源の限られた組み込み機器でも高速に回転 角が算出できる利点もある。図 $5(\mathrm{c})$ は, 指紋領域の重心 $\left(\mu_{i}, \mu_{j}\right)$ と傾き角度 $\theta_{m}$ を示している。指紋センサの面積が 指紋に対して十分に大きいときは， $\theta_{m}$ を用いた傾き補正 法は有効である。

$\langle\mathbf{5} \cdot \mathbf{2}\rangle$ 領域情報を用いた傾き角算出の問題点 図 6 に 示すように，指紋センサからは輪郭が久けている指紋画像 が採取されることも多い。輪郭が欠けている場合，(8) 式で は正しい傾き角度が算出できない場合がある。そこで，(8) 式の角度算出法に加え，輪郭情報を用いて算出した回転角 度を併用して回転補正を行う。

$\langle\mathbf{5} \cdot \mathbf{3}\rangle$ 輪郭情報による傾き角度の補正 輪郭情報に よる傾き角度の算出は以下の手順で行う。まず，指紋領域 画像より指紋画像と背景画像の境界線を抽出する（図 7 参 照)。指紋領域画像 $M_{i, j}$ を水平方向 1 ライン毎に走査した ときの指紋領域の左端と右端を求める。水平方向 1 ライン に対して，注目座標 $i$ をセンサ左端から右方向 $(\rightarrow)$ に走 査していったときの近傍画素の平均值 $A_{i, j}$ を(9) 式により 算出する。平均画素值 $A_{i, j}$ がしきい值 $T H_{b}$ を超えたとこ

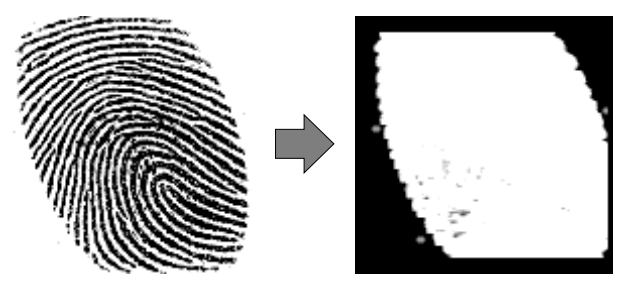

(a) Fingerprint image $F_{i, j}$

(b) Filled image $M_{i, j}$

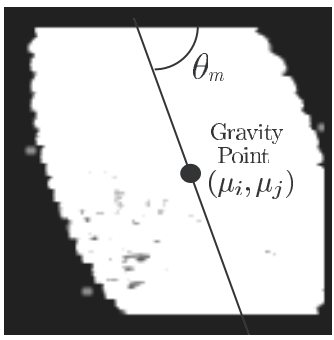

(c) Extracting gradient and gravity point

図 5 指紋領域の抽出

Fig. 5. Extraction of fingerprint area

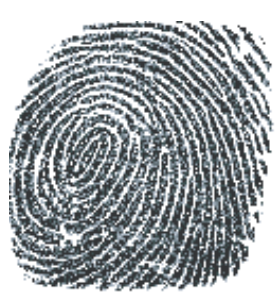

(a) Fingerprint image $F_{i, j}$

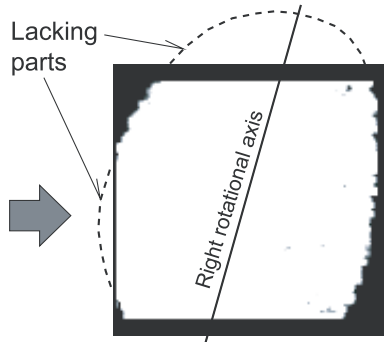

(b) Filled image $M_{i, j}$
図 6 指紋領域を用いた傾き補正の問題点

Fig. 6. Weak point of gradient modification using fingerprint area
ろを指紋領域の左端 $b_{1}(j)$ として検出する。なお，本論文 では $w=2$ ， しきい值 $T H_{b}=100$ としている。

$$
A_{i, j}=\frac{1}{(2 w+1)^{2}} \sum_{v=j-w}^{j+w} \sum_{h=i-w}^{i+w} M_{h, v}
$$

同様に，センサ右端から左方向（ヶ）に探索を行い，指 紋画像の右端 $b_{2}(j)$ を検出する。このようにして検出した $b_{1}(j), b_{2}(j)$ を指紋画像の輪郭情報とする。

以下 $(1) \sim(8)$ の手順により, 輪郭情報 $b_{1}(j), b_{2}(j)$ から 指紋画像の傾き角を算出し，傾き補正を行う。

(1) 図 8 に示すように, 輪郭画像を $90^{\circ}$ 回転させて考え る。以下, $j \rightarrow x, i \rightarrow y, b_{1}(j) \rightarrow b_{1}(x), b_{2}(j) \rightarrow b_{2}(x)$ として説明する。指紋の輪郭線 $b_{1}(x), b_{2}(x)$ のうち, 4 つの直線 $C\left(y=Y_{C}\right), D\left(y=Y_{D}\right), E\left(x=X_{E}\right)$, $F\left(x=X_{F}\right)$ で囲まれた領域 $\mathrm{A}$, 領域 B を傾き角算出 に利用する。なお，本論文では定数 $Y_{C}, Y_{D}, X_{E}, X_{F}$ の值は, $Y_{C}=122, Y_{D}=5, X_{E}=15, X_{F}=112$ として用いている。

(2) 図 9 に示すように, 領域 $\mathrm{A}$ に属する輪郭線 $b_{2}(x)$ を 最小 2 乗法を用いて直線近似する。(10) 式に示す傾き
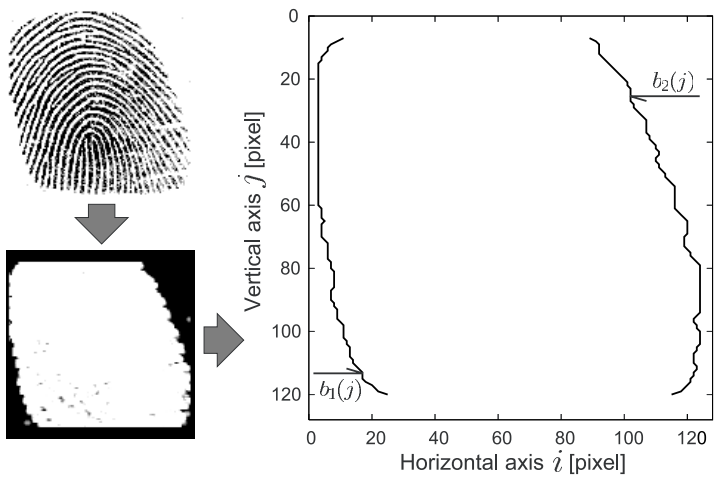

困 7 輪郭情報の抽出

Fig. 7. Extracting contour of fingerprint

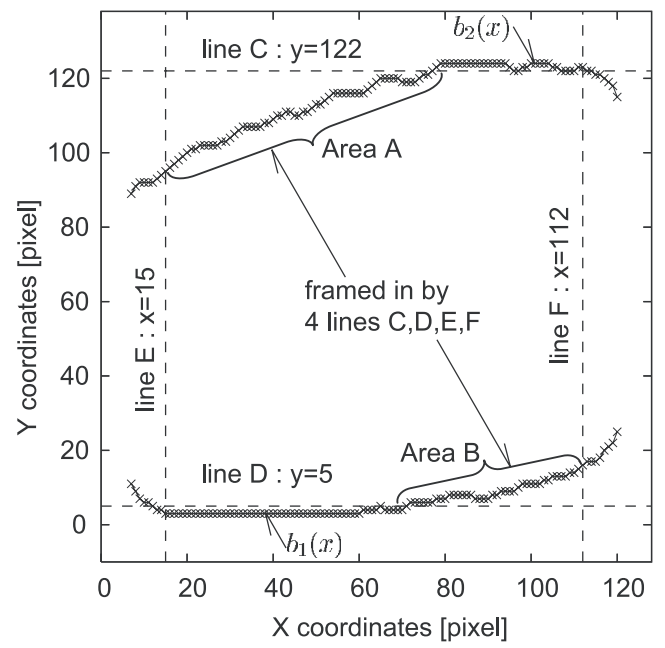

図 8 傾き算出に利用する情報

Fig. 8. Feature for calculating a rotation angle 
$\alpha_{A}, y$ 切片 $\beta_{A}$ の直線 $\mathrm{A}$ を求める。同様に領域 $\mathrm{B}$ の 輪郭線 $b_{1}(x)$ より (11) 式に示す傾き $\alpha_{B}, y$ 切片 $\beta_{B}$ の直線 B を求める。

$$
\begin{aligned}
& y=\alpha_{A} x+\beta_{A} \\
& y=\alpha_{B} x+\beta_{B}
\end{aligned}
$$

(3) 以下，4つの直線 C,D,E,F で囲まれた領域を領域 $\mathrm{CDEF}$ と記す。図 10 に示すように，直線 $\mathrm{A}$ とそれぞ れ直線 $\mathrm{C}$, 直線 $\mathrm{D}$, 直線 $\mathrm{E}$, 直線 $\mathrm{F}$ が成す 4 つの交点 を求める。4つの交点のうち領域 CDEF 内に存在する 2 つの交点をそれぞれ $\left(x_{1 a}, y_{1 a}\right),\left(x_{2 a}, y_{2 a}\right)$ とし, 2 つの交点を結んだ線分を $s l_{a}$ とする。同様に直線 B と 4 つの直線 C,D,E,F の交点を求め, 領域 CDEF 内に 存在する 2 つ交点をそれぞれ $\left(x_{1 b}, y_{1 b}\right),\left(x_{2 b}, y_{2 b}\right)$ とし，2つの交点を結んだ線分を $s l_{b}$ とする。2つの交 点が見つからない場合は，指紋の境界が領域 CDEF に 存在しないことになる。なお図 10 の例では，交点はそ れぞれ 3 つずつしか観察できない。4つ目の交点はそ れぞれ左右の遠方に存在している。

(4) 図 11 に示すように，線分 $s l_{a}$ を $x$ 軸に投影した長 さ $l_{a x}$ を $(12)$ 式により求める。同様に, 線分 $s l_{b}$ を $x$ 軸に投影した長さ $l_{b x}$ を $(13)$ 式により求める。

$$
\begin{aligned}
& l_{a x}=\left|x_{2 a}-x_{1 a}\right| \\
& l_{b x}=\left|x_{2 b}-x_{1 b}\right| \cdots
\end{aligned}
$$

線分 $s l_{a}$ と線分 $s l_{b}$ の両方が算出可能な場合は，(14) 式で表される $L_{o}$ を算出する。 $L_{o}$ は, $s l_{a}$ と $s l_{b}$ の $x$ 軸 方向の分離度を示す。

$$
L_{o}=\left|x_{2 b}-x_{2 a}\right|+\left|x_{1 b}-x_{1 a}\right|
$$

（5）次に，直線 A の信頼性条件を表 1 で定義する。(i), (ii)，(iii）の条件が全て満たされたとき，算出された直 線 A は信頼できると考える。

(i) は「領域 CDEF 内に 2 つの交点が存在する」条 件 (線分 $s l_{a}$ が算出可能な条件), (ii) は「直線 $\mathrm{A}$ の算 出に用いた指紋の輪郭を示す画素数がしきい值 $T H_{n}$

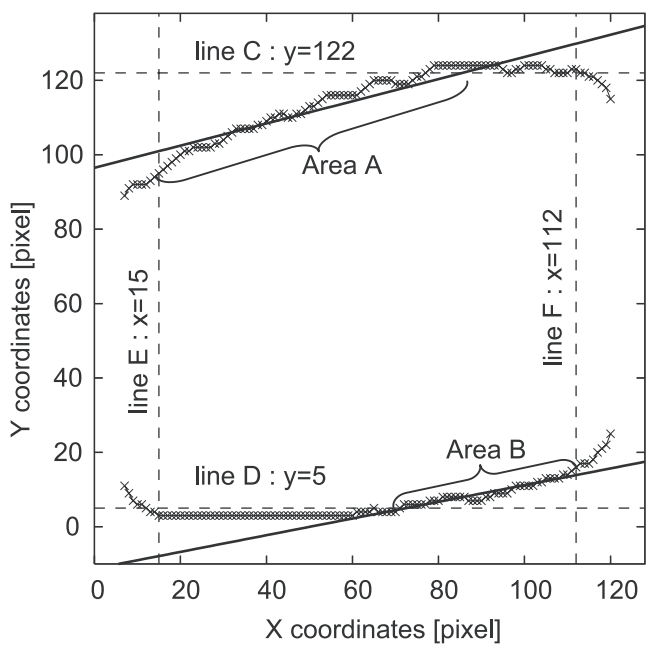

図 9 直線 $\mathrm{A}, \mathrm{B}$ の算出

Fig. 9. Calculating the lines A,B
より多い」条件, (iii) は「直線 A と直線 D の交点の $x$ 座標が $X_{E}<x<X_{F}$ の範囲内に存在しない」条件 である。なお，しきい值 $T H_{n}=10$ としている。

（6）同様に, 直線 B の信頼性条件を表 2 で定義する。(i), (ii), (iii)の条件が全て満たされたとき, 算出された直 線 B は信頼できると考える。

（7）以下 $(\mathrm{a}) \sim(\mathrm{d})$ の場合分けに従って角度 $\theta$ を算出する。 (a) 直線 A, 直線 B 両方が表 1 , 表 2 の信頼性条件を 満たさない場合

直線 $\mathrm{A} ， \mathrm{~B}$ の信頼性は低いと考えられるため，角 度 $\theta$ は, (15) 式により, 指紋領域情報を用いて算出 した角度 $\theta_{m}$ で置き換える。

$$
\theta=\theta_{m}
$$

(b) 直線 A が表 1 の信頼性条件を満たし, 直線 B が 表 2 の信頼性条件を満たさない場合

(b-1) $l_{a x}<T H_{L A}$ のとき

直線 A は信頼性条件は満たしているが, $l_{a x}$

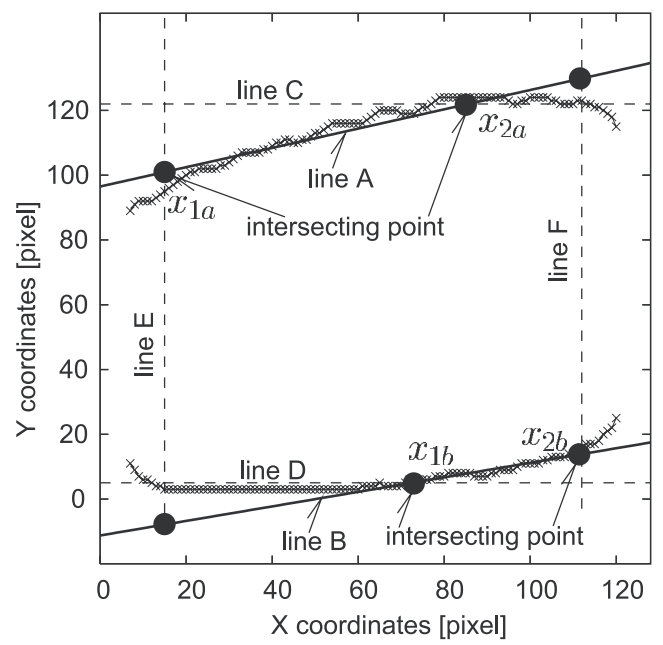

図 10 交点の算出

Fig. 10. Calculating the intersecting points

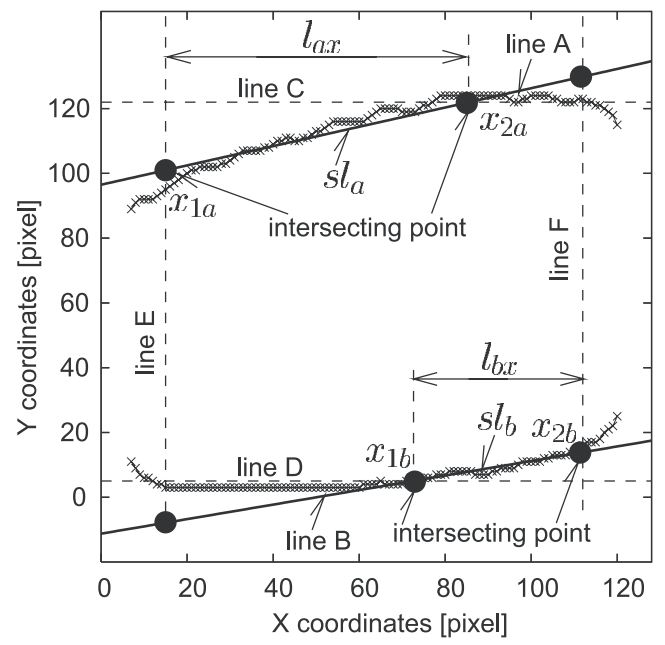

図 11 線分 $s l_{a}$ と線分 $s l_{b}$

Fig. 11. Line Segment $s l_{a}$ and $s l_{b}$ 
表 1 直線 $\mathrm{A}$ の信頼性条件

Table 1. The terms of reliable line A

$\begin{array}{ll}\text { (i). } & \left(x_{1 a}, y_{1 a}\right),\left(x_{2 a}, y_{2 a}\right) \in C D E F \\ \text { (ii). } & l_{a x}>T H_{n} \\ \text { (iii). } & \left(Y_{D}-\beta_{A}\right) / \alpha_{A} \leq X_{E} \quad \text { or }\left(Y_{D}-\beta_{A}\right) / \alpha_{A} \geq X_{F}\end{array}$

表 2 直線 B の信頼性条件

Table 2. The terms of reliable line B

(i). $\left(x_{1 b}, y_{1 b}\right),\left(x_{2 b}, y_{2 b}\right) \in C D E F$

(ii). $\quad l_{b x}>T H_{n}$

(iii). $\left(Y_{C}-\beta_{B}\right) / \alpha_{B} \leq X_{E}$ or $\left(Y_{C}-\beta_{B}\right) / \alpha_{B} \geq X_{F}$

が一定しきい值 $T H_{L A}$ より短いため, 直線 $\mathrm{A}$ の傾きを用いて回転補正を行うべきではない。

角度 $\theta$ は，(15) 式により，指紋領域情報を

用いて算出した角度 $\theta_{m}$ で置き換える。しき

い值 $T H_{L A}=50$ としている。

(b-2) $\quad l_{a x} \geq T H_{L A}$ のとき

角度 $\theta$ は, 直線 $\mathrm{A}$ の傾き $\alpha_{a}$ を用いて角度

$\theta$ は $(16)$ 式により算出する。

$$
\theta=\tan ^{-1}\left(\alpha_{a}\right)
$$

(c) 直線 B が表 2 の信頼性条件を満たし，直線 A が 表 1 の信頼性条件を満たさない場合

(c-1) $l_{b x}<T H_{L B}$ のとき

直線 B は信頼性条件は満たしているが， $l_{b x}$ が一定しきい值 $T H_{L B}$ より短いため, 直線 $\mathrm{B}$ の傾きを用いて回転補正を行うべきではない。

角度 $\theta$ は，(15) 式により，指紋領域情報を 用いて算出した角度 $\theta_{m}$ で置き換える。しき い值 $T H_{L B}=50$ としている。

(c-2) $\quad l_{b x} \geq T H_{L B}$ のとき

角度 $\theta$ は, 直線 B の傾き $\alpha_{b}$ を用いて (17) 式により算出する。

$$
\theta=\tan ^{-1}\left(\alpha_{b}\right)
$$

(d) 直線 A, 直線 B 両方が表 1 , 表 2 の信頼性条件を 満たす場合

(d-1) $L_{o}<T H_{L O}$ のとき

線分 $s l_{a}$ と線分 $s l_{b}$ の $x$ 軸方向の分離度を 示す $L_{O}$ が，一定しきい值 $T H_{L O}$ より小さい とき, $s l_{a}$ と $s l_{b}\left(l_{a x}\right.$ と $\left.l_{b x}\right)$ は，指の先端な ど指紋が細くなる部分を捉えている場合があ る。入力画像は図 12 のように回転の小さな 画像である可能性があるため, $l_{a x}, l_{b x}$ から は傾きを算出しない。

角度 $\theta$ は，(15) 式により，指紋領域情報を 用いて算出した角度 $\theta_{m}$ で置き換える。しき い值 $T H_{L O}=50$ としている。

(d-2) $L_{o} \geq T H_{L O}$ のとき

$l_{a x}, l_{b x}$ と直線 $\mathrm{A}, \mathrm{B}$ の傾き $\alpha_{a}, \alpha_{b}$ を用 いて, 角度 $\theta$ は (18) 式により算出する。な

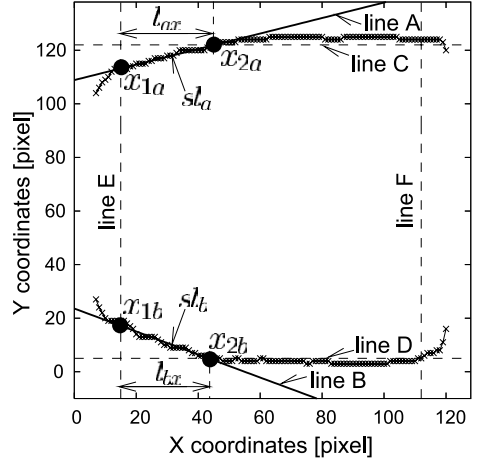

(b) Fingerprint contour and Lines A, B

(a) Fingerprint image

図 $12 L_{o}$ が小さい場合の直線 $\mathrm{A}, \mathrm{B}$

Fig. 12. Line A and $\mathrm{B}$ in the case of $L_{o}$ is small

\begin{tabular}{|c|c|}
\hline \multirow{3}{*}{$\begin{array}{l}\text { (a) } \\
\text { Both line A and line B } \\
\text { are not computable. } \\
\text { or } \\
\text { Both line A and line B } \\
\text { have no dependability. }\end{array}$} & $(b-2)$ \\
\hline & $l_{a x} \geq T H_{L A}$ \\
\hline & $\begin{array}{l}(\mathrm{b}-1) \\
\quad l_{a x}<T H_{L A}\end{array}$ \\
\hline$(\mathrm{c}-1)$ & $(\mathrm{d}-1)$ \\
\hline$l_{b x}<T H_{L B}$ & $I_{I_{O}}<T H_{L O}$ \\
\hline$(\mathrm{c}-2)$ & $(\mathrm{d}-2)$ \\
\hline$l_{b x} \geq T H_{L B}$ & $L_{O} \geq T H_{L O}$ \\
\hline
\end{tabular}

(b) Only line A have dependability.

(c) Only line B have dependability. (d) Both line A and line B have dependability.

Modifying the gradient using fingerprint area.

$\square$ Modifying the gradient using fingerprint contour.

図 13 条件 $(\mathrm{a}) \sim(\mathrm{d})$ の分類

Fig. 13. Classification of term (a) $\sim(d)$

お，(18) 式では， $l_{a x}$ と $l_{b x}$ はそれぞれ直線 $\mathrm{A}$ ，直線 $\mathrm{B}$ の信頼性に比例する尺度として扱っ ている。

$$
\theta=\tan ^{-1}\left(\frac{l_{a x} \alpha_{a}+l_{b x} \alpha_{b}}{l_{a x}+l_{b x}}\right) \ldots
$$

（8）（7）で算出した $\theta$ を傾き角，(4) 式・(5) 式で算出し た $\left(\mu_{i}, \mu_{j}\right)$ を回転中心として，指紋画像の傾き補正を 行う。なお，傾き補正に用いるアフィン変換には固定 小数点演算による高速化を施してある。

$\langle\mathbf{5} \cdot \mathbf{4}\rangle$ 条件 $(\mathbf{a}) \sim(\mathrm{d})$ の分類 条件 $(\mathrm{a}) \sim(\mathrm{d})$ の場合 分けを図示したものが図 13 である。図中の灰色の領域が 『指紋領域を用いて回転補正を行う条件』，白色の領域が 『指紋の輪郭を用いて回転補正を行う条件』である。条件 (b-1),(c-1),(d-1) は『指紋輪郭から抽出した直線の信頼性 はあるが，その直線を用いて回転補正すべきでない条件』 に相当する。

指紋領域を用いて回転補正された指紋画像を図 14 に示 す。全指紋データ 1275 枚中に占める (a),(b-1),(c-1),(d-1) の枚数は，それぞれ 0 枚， 18 枚，5枚，791 枚となってい 


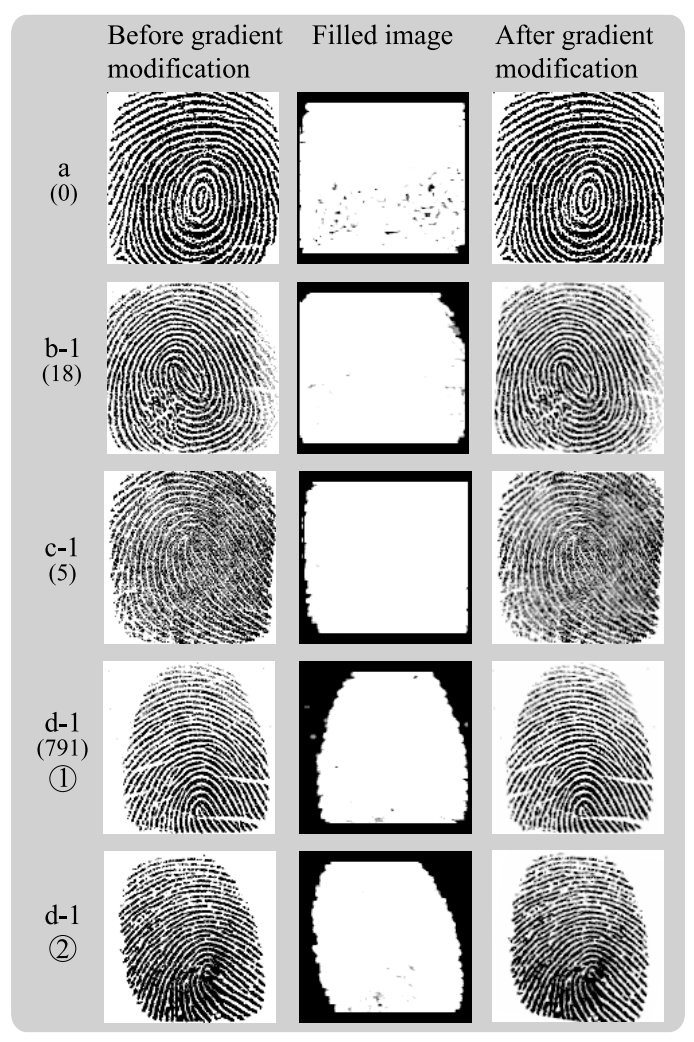

図 14 指紋領域を用いて回転補正された画像

Fig. 14. Fingerprint images modified gradient using fingerprint area

る。本実験で採取した指紋データ中には (a) に分類される 指紋画像は存在しなかった。稀な例ではあるが，条件 (a)に 分類される指紋画像は余白がほとんど存在しないため，算 出された回転角度は極めて小さな值となる。(b-1) は『指紋 画像右側の輪郭の信頼性はあるが，それを回転補正に用い るべきではない』条件，(c-1) は『指紋画像左側の輪郭の信 頼性はあるが，それを回転補正に用いるべきではない』条 件である。(a),(b-1),(c-1) の例に示すように，余白が小さ くなると回転補正角度は小さな值となり，大幅な補正は行 われなくなる。(d-1) は『指紋画像両側の輪郭の信頼性はあ るが，輪郭よりは指紋領域を利用した方が安全に回転角を 算出できると判定した』場合である。(d-1) 1 1 は真っ直ぐに 押捺された指紋画像，(d-1) (2)は斜めに押捺された指紋画 像を回転補正した例である。

図 15 は，指紋輪郭を用いて回転補正された画像である。 (b-2) は指紋画像の右側の輪郭を用いて回転補正した例，(c2) は指紋画像の左側輪郭を用いて回転補正した例である。 (d-2) は，指紋画像の左右両側の輪郭を用いて回転補正した 例である。全指紋データ 1275 枚中に占める (b-2), (c-2), (d2) の枚数は，それぞれ 32 枚， 36 枚，393 枚となっている。

\section{6. 指紋画像の回転補正実験}

$\langle\mathbf{6} \cdot \mathbf{1}\rangle$ 実験条件 本人 1 名につき 25 枚の指紋画像 データのうち, 傾き角 $0^{\circ}$ の画像 5 枚を登録パターンとす

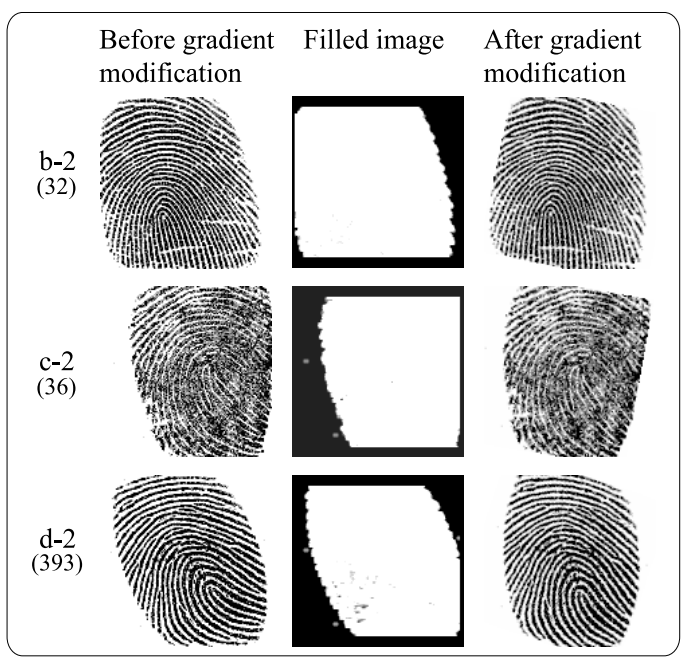

図 15 指紋輪郭を用いて回転補正された画像

Fig. 15. Fingerprint images modified gradient using fingerprint contour

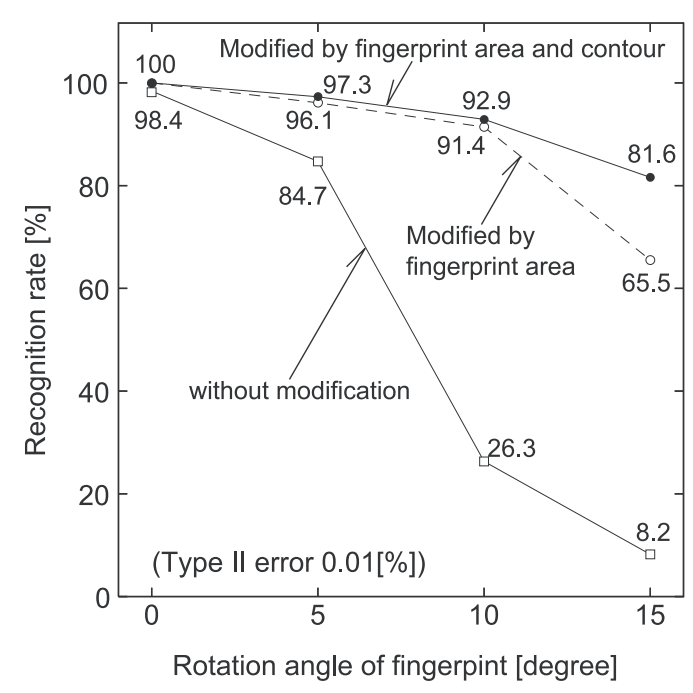

困 16 傾き補正処理の効果

Fig. 16. Effectiveness of gradient modification

る。残りの $0^{\circ}, 5^{\circ}, 10^{\circ}, 15^{\circ}$ 回転した画像各 5 枚（計 20 枚）を照合用パターンとする。しきい值は，他人受理率が 0.01[\%] となるように設定した 51 人の登録者全員に共通の 值を用いる。51名全員をそれぞれ本人としたときの距離計 算を行い, 他人受理率を $0.01[\%]$ としたときの本人受理率を 算出する。このときの他人指の総数は $50 \times 20 \times 51=51000$ 個, 本人の総数は $51 \times 20=1020$ 個である。

$\langle\mathbf{6} \cdot \mathbf{2}\rangle$ 照合精度の評価 図 16 は, 指紋画像の傾き角 度と, 回転補正前・回転補正後の本人受理率を比較した結果 である。回転補正前の指紋画像では, 入力指の傾き角度が $0^{\circ}, 5^{\circ}, 10^{\circ}, 15^{\circ}$ と増加するに従って, 照合率は $98.4[\%]$, 84.7[\%], 26.3[\%], 8.2[\%] と急激に低下していく。特に, 入 力指が 15 傾いた場合では, $8.2[\%]$ の低い照合率となって いる。指紋領域情報を用いて傾き補正を行うことで，入力 指が 15 傾いたときの照合率は $65.5[\%]$ まで改善される。 


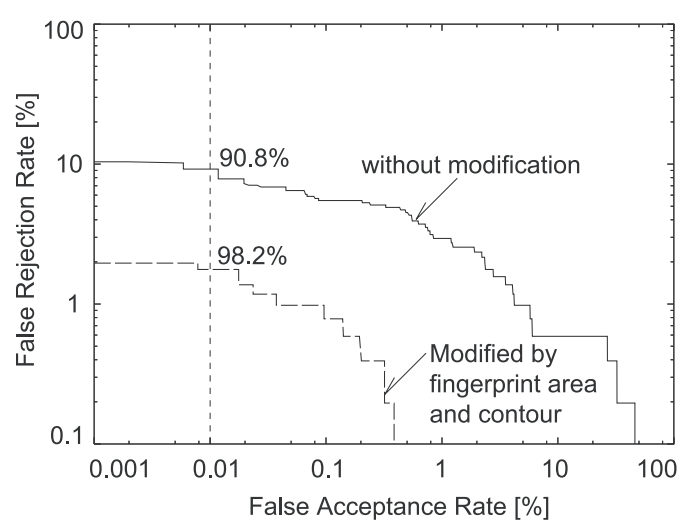

図 17 傾き補正前・補正後の ROC カーブ (入力指の傾き:0 $05^{\circ}$ )

Fig. 17. ROC curves (Angle of rotation:0 $\sim 5^{\circ}$ )

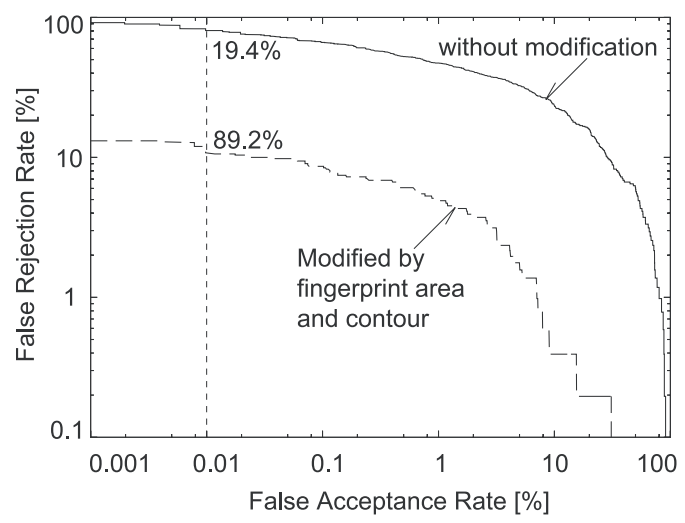

図 18 傾き補正前・補正後の ROC カーブ (入力指の傾き : $10 \sim 15^{\circ}$ )

Fig. 18. ROC curves (Angle of rotation:10 $15^{\circ}$ )

さらに，指紋領域・輪郭情報を用いた傾き補正では，照合 率は 81.6[\%]にまで改善される。

図 17 は，傾き角 $0^{\circ}$ と $5^{\circ}$ の入力指について傾き補正前と 傾き補正後の ROC (Receiver Operating Chracteristic) カーブを比較したものである。他人受理率 $0.01[\%]$ のとき， 本人受理率は回転補正前で $90.8[\%]$ ，回転補正後で $98.2[\%]$ である。回転補正処理により，照合率は 7.4[\%]改善されて いる。実環境において，装置に慣れたユーザが入力する指 紋の傾き角度は $0^{\circ} \sim 5^{\circ}$ に納まる傾向にある。図 17 は，装 置に慣れたユーザに対する指入力の受容性が傾き補正によ り 7.4[\%] 向上したことを示している。

一方，図 18 は傾き角 $10^{\circ}$ と $15^{\circ}$ の入力指について求め たROC カーブである。他人受理率 0.01[\%] のとき，回転 補正前の本人受理率は 19.4[\%], 回転補正後で 89.2[\%] で ある。回転補正処理により，照合率は 69.8[\%] 向上してい る。指ガイドの設けられた入退室管理用途の指紋照合装置 では，入力指が $15{ }^{\circ}$ 傾くことは稀である。しかし，装置に 慣れていないユーザが指を傾き気味に入力することが想定 される。回転補正処理により，指紋照合装置の入力受容性 は大幅に改善されることが期待できる。 $\langle\mathbf{6} \cdot \mathbf{3}\rangle$ 照合時間の評価 クロック周波数 $1[\mathrm{GHz}], \mathrm{OS}$ にWindowsXp を搭載した $\mathrm{PC}$ で，指紋の傾き角算出から 回転補正が終了するまでの処理時間は約 $3.2[\mathrm{~ms}]$ であった。 $\mathrm{PC}$ の処理時間は 10 万回の回転補正処理を行ったときの平 均值として算出した。一方，日立社製の安価なマイクロプ ロセッサ SH-3e(SH7718R 130[MIPS] 100[MHz]) を搭載 した組み达み機器では，回転補正時間は約 $150[\mathrm{~ms}]$ である。 本手法は, CPU に負担をかけることなく非常に高い効果 を発揮する斜め入力対策法である。

\section{7. むすび}

指紋領域と輪郭情報を利用した指紋画像の回転補正法に ついて述べ，その有効性を示した。指紋照合装置に慣れて いないユーザは指を斜めに入力する傾向にあり，照合率の 低下を招くことがある。本研究は，実環境で動作する指紋 照合装置の指置き受容性を向上させる目的で行った。

指を $0^{\circ}, 5^{\circ}, 10^{\circ}, 15^{\circ}$ 傾けて採取した指紋画像デー 夕を用いてアルゴリズムの評価を行った。指ガイドの設け られた入退出管理用途の指紋照合装置では，装置に慣れた ユーザが指を押捺するときの傾き角は $0^{\circ} \sim 5^{\circ}$ に納まる傾 向にある。他人受理率を 0.01[\%]に固定したとき，傾き角 $0^{\circ} \sim 5 \circ$ の指紋画像から算出した本人受理率は 90.8[\%] で あった。回転補正を行うことにより，本人受理率 98.2[\%] にまで改善された。

一方，傾き角 $10^{\circ} \sim 15^{\circ}$ の指紋画像から算出した本人受 理率は，回転補正なしの場合で 19.4[\%] であったが，回転 補正を行うことにより 89.2[\%] まで改善された。実環境で 指紋の入力角が $15^{\circ}$ 傾くことは稀であるが，本回転補正法 により，傾き入力の受容性は飛躍的に改善する。より初心 者に使い易い指紋照合装置を造ることが可能である。

回転補正処理時間はクロック周波数 $1[\mathrm{GHz}]$ の $\mathrm{PC}$ で $3.2[\mathrm{~ms}]$ と非常に高速である。また，クロック周波数の $100[\mathrm{MHz}]$ の安価なマイクロプロセッサを搭載した組み込 み機器では，回転補正時間は約 $150[\mathrm{~ms}]$ である。本回転補 正法は，ハードウェア資源の限られた組み込み機器への搭 載にも適している。今後も,『誰にでも使い易い便利な指紋 照合装置』の開発を目指した研究を行っていきたい。 (平成 18 年 7 月 25 日受付，平成 18 年 12 月 20 日再受付)

\section{文献}

(1) K. Sasagawa: "Biometric Security by Fingerprint", IEICE, Vol.89, No.1 (2006) (in Japanese) 笹川耕一：「指紋のバイオメトリクスセキュリティ」，信会誌，89, 1, pp.31-35 (2006)

(2) K. Asai, Y. Hoshino, and K. Kiji: "Automated Fingerprint Identification by Minutia-Network Feature - Feature Extraction Processes-", IEICE Trans., D-II, Vol.J72-DII, No.5, pp.724-732(1989) (in Japanese)

浅井 鉱・星野幸夫・木地和夫・「マニューシャネットワーク特徵に よる自動指紋照合一特徴抽出過程－」，信学論 (D), J72-D-II, 5, pp.724-732 (1989)

(3) K. Asai, Y. Hoshino, and K. Kiji: "Automated Fingerprint Identification by Minutia-Network Feature - Matching 
Processes-", IEICE Trans., D-II, Vol.J72-DII, No.5, pp.733740 (1989) (in Japanese)

浅井 鉱・星野幸夫・木地和夫：「マニューシャネットワーク特垷 による自動指紋照合一照合過程一」, 信学論 (D), J72-D-II, 5 , pp.733-740 (1989)

(4) T. Wakahara, Y. Kimura, A. Suzuki, A. Shio, and M. Sano: "Fingerprint Verification Using Ridge Direction Distribution and Minutiae Correspondence", IEICE Trans. D-II, Vol.J86DII, No.1, pp.63-71 (2003) (in Japanese)

若原 徹・木村義政・鈴木 章・塩 昭夫・佐野睦夫 : 「指紋隆線方 向分布とマニューシャ対応付けを用いた指紋照合」, 信学論 (D-II), J86-D-II, 1, pp.63-71 (2003)

(5) T. Kobayashi, H. Nakajima, M. Morikawa, and A. Katsumata: "Fingerprint Identification Device for Homes Using Rotation-Invariant Phase-Only Correlation", Yamatake Savemation Review, 8, pp.34-39 (2000) (in Japanese) 小林孝次・中島 寛・森川 誠·勝亦 敦:「回転不変位相限定相 関を用いた住宅用指紋照合装置」，（株）山武 Savemation Review， 8, pp.34-39 (2000)

(6) A.W. Senior and R.M. Bolle: "Improved Fingerprint Matching by Distortion Removal", IEICE Trans., E84-D, 7, pp.825-832 (2001)

(7) K. Ito, H. Nakajima, K. Kobayashi, T. Aoki, and T. Higuchi "A Fingerprint Matching Algorithm Using Phase-Only Correlation", IEICE Trans., E87-A, 3, pp.682-691 (2004)

(8) A.S. Rikin, D. Li, T. Isshiki, and H. Kunieda: "A Fingerprint Matching Using Minutia Ridge Shape for Low Cost Matchon-Card Systems", IEICE Trans., E88-A, 5, pp.1305-1312 (2005)

(9) Kovacs-Vajna S. M.: "A Fingerprint Verification System Based on Triangular Matching and Dynamic Time Warping", IEEE Trans. Pattern Anal. \& Mach. Intell., Vol.22, pp.1266$1276(2000)$

(10) T. Umezaki, H. Takeuchi, and H. Fujiyoshi: "Comparison of the Fingerprint Verification Meshods Based on the Discrete and Continuous Hidden Markov Model", Vol.118-C, No.6, pp.955-960 (1997-6) (in Japanese)

梅崎太造 ・竹内英世・藤吉弘亘 :「離散及び連続出力分布型 HMM による指紋照合法の比較」, 電学論 (C), 118-C, 6, pp.955-960 (1997-6)

(11) N. Matsumoto, S. Sato, H. Fujiyoshi, and T. Umezaki: "Evaluation of a Fingerprint Verification Method Based on LPC Analysis", Trans. IEE Japan, Vol.122-C, No.5, pp.799-807 (2002-5) (in Japanese)

松本憲幸・佐藤省三・藤吉弘亘・梅崎太造 $:$ 「LPC 分析に基づく指 紋照合法の評価」, 電学論 $(\mathrm{C}), \mathbf{1 2 2 - C}, 5$, pp.799-807 (2002-5)

(12) H. Takeuchi, T. Umezaki, N. Matsumoto, and K. Hirabayashi: "Evaluation of Low Quality Images and Imaging Enhancement Methods for Fingerprint Verification", $I E$ ICE Trans., D-II, Vol.J87-D-II, No.2, pp.574-585 (2004) (in Japanese)

竹内英世・梅崎太造・松本憲幸・平林勝巳 :「かすれ指紋画像の判 定・復元機能を持つ指紋照合法」, 信学論 (D-II), J87-D-II, 2, pp.574-585 (2004)

(13) H. Takeuchi, N. Matsumoto, K Kuwayama, and T. Umezaki: "Evaluation of Fingerprint Images Captured by Optical Fingerprint Scanner", Trans. IEE Japan, Vol.124-C, No.3, pp.761-768 (2004-3) (in Japanese)

竹内英世・松本憲幸・桑山清明・梅崎太造 : 「光学式指紋スキャナ により採取された指紋画質の評価方法」, 電学論 $(C), \mathbf{1 2 4}-\mathrm{C}, 3$, pp.761-768 (2004-3)

（14）星野幸夫・国方純一・高橋良英：「縞パターン照合装置」，特許第 2944557 号, 6,(1999)

（15）木村義政・角越和也・伴野 明：「指紋画像照合方法掞よび指紋画 像照合装置」, 公開特許 $2001-243465,9,(2001)$ （16）新崎＼cjkstart卓：「指紋検出センサ」, 公開特許平 06-149983,6,(1994)

(17) 坂本美津夫:「指紋読み取り装置」, 公開特許平 10-269344,10,(1998)

（18）中山武彦：「指紋 照合装置」，公開特許 2001-229364,8,(2001)

（19）斎藤賢一 - 重松智志 - 小中信典 - 岡崎幸夫 - 山口 力 - 首藤炶樹 : 「指紋 照合装置」, 公開特許 2002-83291,3,(2002)

（20）井上清寿：「指紋 入力装置」，公開特許 2006-79502,3,(2006)

(21) 岩本 彰・渡辺哲幸:「指紋 認証入力装置」, 公開特許 2002 $74343,3,(2002)$

竹 内 英 世（正員）1973 年 1 月 19 日生。1995 年 中部大 ·

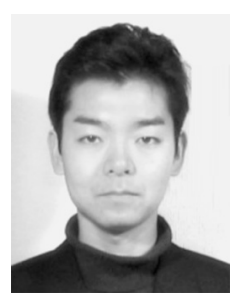
工・電子卒業。1997 同大学院博士前期課程修了。 同年 中央発條（株）入社， 2004 年（株）ディー。 ディー・エス出向，現在に至る。指紋照合，画像処 理に関する研究に従事。電子情報通信学会会員。

保 黒 政 大 (非会員) 1970 年 9 月 20 日生。1993 年 中部

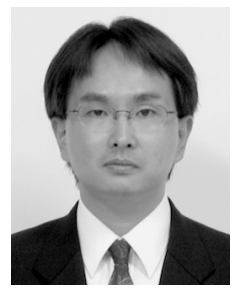
大 $\cdot$ 工・電子卒業。1 995 年同大学院博士前期課程 修了。2002 年（株）ディー・ディー・エス入社。 2003 年名工大大学院博士後期課程入学, 現在に 至る。画像処理に関する研究に従事。電子情報通 信学会，日本福祉工学会各会員。

松 本 憲 幸 (非会員) 1968 年 5 月 7 日生。1991 年 中部大・

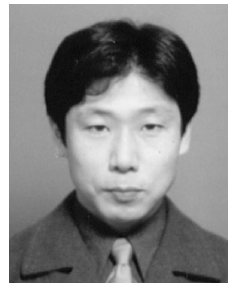
工・電子卒業。1993 年同大学院博士前期課程修 了。同年 中央発條（株）入社, 現在に至る。指紋 照合装置の開発，画像処理の実環境への応用に関 する研究に従事。電子情報通信学会会員。

梅 崎 太 造 (正員) 1959 年 7 月 27 日生。 1982 年豊橋技科

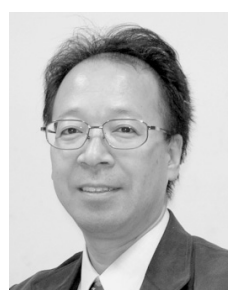
大 · 工 · 情報卒業。1987 年 名大大学院博士課程 了。同年 4 月名大助手。1990 年中部大講師, 1992 年同大学助教授。1993 1994 年 カーネギーメロ ン大学客員研究員。1999 年中部大教授。2003 年 名工大教授。工博。音声 - 画像情報処理, 聴覚障 害児教育，福祉ロボットの研究に従事。情報処理 学会, 日本音響学会, 電子情報通信学会, 日本福 祉工学会, ヒューマンインターフェイス学会各会員。 